\title{
KONFLIKTY ETNICZNE W ŚWIETLE SOCJOLOGII KLASYCZNEJ I PSYCHOLOGII SPOLECZNEJ (na przykładzie Kresów południowo-wschodnich // Rzeczypospolitej)
}

\author{
ETHNIC CONFLICT IN THE VIEW OF CLASSICAL \\ SOCIOLOGY AND SOCIAL PSYCHOLOGY \\ Ion the example of south-eastern Borderlands \\ of the Second Polish Republic)
}

\begin{abstract}
The goal of the article is to demonstrate that social conflicts, especially those that take the form of ethnic conflicts, constitute one of the many causes of martyrdom. The article is divided into four sections. The considered topics lead to the conclusion that the social and ethnic issues are diverse and complex as demonstrated in the theories of the classics of sociology and contemporary theoreticians dealing with ethnic conflicts from the point of view of sociology and social psychology.
\end{abstract}

Key words: ethnic conflicts; martyrdom; Poland; southeastern Borderlands

\section{Streszczenie}

RENATA POMARAŃSKA Rzeszów

Celem artykułu jest wykazanie, że konflikty społeczne, zwłaszcza te, które przyjmują postać konfliktów etnicznych, stanowią jedną z wielu przyczyn martyrologii. Artykuł został podzielony na cztery części. Rozpatrywane zagadnienia prowadzą do

E-mail: renep@wp.pl This work was supported by the author's own resources.

No competing interests have been declared

This is an Open Access article distributed under the terms of the Creative Commons Attribution 3.0 PL License (creativecommons.org/licenses/by/3.0/pl/), which permits redistribution, commercial and non-commercial, provided that the article is properly cited. (C) The Author(s) 2016.

Publisher: Institute of Slavic Studies, Polish Academy of Sciences [Wydawca: Instytut Slawistyki PAN] 
wniosku, że problemy społeczne i etniczne są zróżnicowane i złożone, jak wykazano w teorii klasyków socjologii oraz współczesnych teoretyków zajmujących się konfliktami etnicznymi z punktu widzenia socjologii i psychologii społecznej.

Stowa kluczowe: konflikty etniczne; martyrologia; Polska; Kresy południowo-wschodnie

\section{WSTĘP}

$\mathrm{N}$

iniejszy artykuł stawia sobie za cel przedstawienie konfliktów etnicznych jako jednej z wielu przyczyn martyrologii na Kresach południowo-wschodnich. Zostaną poruszone następujące wątki: teoria ras według L. Gumplowicza, "swoi" i "obcy" jako podmiot konfliktu w ujęciu F. Znanieckiego, koncepcje pojęciowo-teoretyczne dotyczące konfliktów etnicznych w ujęciu klasyków socjologii) oraz próba psychologicznego wyjaśnienia wrogości wobec „obcych” (,innych”).

\section{TEORIA RAS WED $U$ UG L. GUMPLOWICZA}

L. Gumplowicz używał pojęcia rasy, ale jak pisze J. Szacki w Historii myśli socjologicznej, „odrzucał zarówno rasistowski podział ras na lepsze i gorsze, jak i przekonanie, iż głównym wyróżnikiem rasy są cechy fizyczne. W jego osobliwym «rasizmie» jedność krwi była wtórna w stosunku do jedności kultury" (Szacki, 2011, s. 369). Gumplowicz uważał rasę za wytwór czynników społeczno-kulturowych. W Rassenkampf pisał:

\footnotetext{
Rasa nie jest i nie może być dzisiaj nigdzie ujmowana jedynie jako pojęcie przyrodnicze w ścisłym tego słowa znaczeniu. Jest ona coraz bardziej pojęciem historycznym. Rasa to nie jest produkt procesu naturalnego $w$ dotychczasowym tego słowa rozumieniu, ale wytwór procesu historycznego, który jest ostatecznie także procesem naturalnym. Rasa jest to wspólnota wytworzona w historycznym rozwoju społecznym, wspólnota, która ma swój początek w momentach duchowych (język, religia, obyczaj, prawo, kultura), dopiero od tych duchowych momentów zaczyna się kształtować prawdziwa więź, która ją spaja - jedność krwi (Mirek, 1930, s. 28).
}

Według Gumplowicza tak pojmowane rasy (narody i grupy etniczne) prowadzą ze sobą nieustanną walkę. Konflikt i walka pomiędzy grupami są, jego zdaniem, głównymi czynnikami życia społecznego. Naukowiec wysunął także hipotezę o "wieloplemienności", według której ludzkość nie przedstawia jednej całości, lecz kombinację heterogenicznych grup mających odrębną geneze i charakter. Socjolog ten posługiwał się pojęciem rasy, rozumianej jako grupa etniczna lub narodowa, którą łączą takie elementy jak język, religia, obyczaje, prawo, kultura etc. Zakładał nie tylko nieustanny podział ludzkości na rasy, ale także stałą wrogość między nimi. Jak słusznie zauważa Jerzy Szacki:

Solidarności w obrębie każdej grupy towarzyszy zawsze wrogość do innych grup; altruizmowi jednostek wewnątrz własnej grupy - bezwzględny egoizm w stosunkach z członkami grup obcych (...). Grupa społeczna zawsze i wszędzie dąży, jeśli nie do eksterminacji, to do podporządkowania sobie, zniewolenia i eksploatacji jakiejś innej grupy (Szacki, 2011, s. 370). 
Dowodem na to są dzieje ludzkości pokazujące nieustanną walkę różnych grup społecznych. Historia ludzkości jest dla Gumplowicza tylko krwawym ponurym dramatem i wieczną walką, która nigdy nie ma końca i nie prowadzi do określonego wyższego celu. Teoria ras Gumplowicza była inspiracją dla wielu socjologów zainteresowanych problematyką ras i konfliktów etnicznych. Odnosił się do niej także Florian Znaniecki.

\section{"SWOI" I "OBCY" JAKO PODMIOT KONFLIKTU W UJĘCIU F. ZNANIECKIEGO}

F. Znaniecki odrzucił podejście L. Gumplowicza i jego kontynuatorów, W. G. Summera i A. G. Kellera, wyprowadzające antagonizm do obcych z instynktu samozachowawczego pobudzającego do walki o byt. Praca Znanieckiego skupiała się na gromadzeniu przykładów obalających hipotezy Gumplowicza i innych w odniesieniu do rozumienia pojęcia "obcy".

W literaturze socjologicznej istnieją dwie zasadnicze interpretacje pojęcia „obcy". Według pierwszej z nich socjologowie za obcych uważają tych, których z daną jednostką nie łączy żadna więź społeczna. Drugie zaś podejście za obcych uważa tych, którzy się znacznie od niej różnią: rasowo, plemiennie, kulturalnie itp. W pierwszym przypadku ważne jest rozumienie pojęcia więzi społecznej, a przez nią można zarówno rozumieć wspólną przynależność do grupy, jak i zwykłe przebywanie jednostek i mniejszych grup obok siebie. W tym więc podejściu obcymi są nie członkowie danej grupy w przeciwieństwie do swoich - członków tej grupy. Zgodnie zaś z drugą interpretacją za obcych można uznać tych, z którymi jednostka w ogóle się nie stykała lub miała kontakt ograniczony. W tym rozumieniu "obcy" jest znaczeniowo podobny do "nieznany”. W Studiach nad antagonizmem do obcych Znaniecki pisze na temat przynależności grupowej:

(...) Nietrudno wykazać, że brak wspólnej przynależności grupowej nie może być tą cechą, z której by zawsze i wszędzie wynikała obcość; tylko przyzwyczajenie do nieścisłego ujmowania zagadnień socjologicznych i zadowalania się ogólnikowymi, „przybliżonymi” rozwiązaniami tłumaczy popularność tego sprawdzianu. Prawda, że na niższych szczeblach rozwoju jego niedostateczność mniej rzuca się w oczy, a socjologowie do niedawna zajmowali się antagonizmem do obcych głównie na niższych szczeblach (...). Lecz nawet $w$ tego rodzaju wypadkach, gdy względnie najłatwiej utożsamić obcość z brakiem wspólnej przynależności grupowej, pojawiają się trudności. Już w obrębie wyodrębnionego plemienia istnieją wszak mniejsze grupy - rodziny, rody, fratrie, związki tajne.. stosując tu zasadę, że obcość wynika z braku przynależności do tej samej grupy, musimy ująć nienależących do rodziny jako obcych w odniesieniu do członków rodziny, nienależących do rodu jako obcych w odniesieniu do członków rodziny itd., chociaż jako współczłonkowie plemienia są oni "swoi" (Znaniecki, 1931, ss. 8-9).

W ślad za tą myślą Znaniecki dostrzegł pułapkę stopniowania obcości, a co za tym idzie również swojskości. Pytał: „Kto jest bardziej obcy - członek rodu, należący do rodziny, czy członek rodziny, nienależący do rodu?" (Znaniecki, 1931, s. 10). Jeśli nawet w kregu rodziny może się znaleźć obcy, to tym bardziej w obrębie społeczeństw wyższych, cywilizowanych. Stosując kryterium przynależności grupowej, z łatwością można się doszukać mniej i bardziej obcych. W ten sposób Znaniecki zwrócił uwagę na pozorność i niedorzeczność ustalania obcości na podstawie przynależności grupowej.

Taka sama zawodność dotyczy określania obcości za pomocą kryterium odmienności i różnic. Autor Studiów nad antagonizmem do obcych przywołuje tu przykład białych anglosaskiego pochodzenia i Murzynów w Stanach Zjednoczonych. Pisze on: 
Różnica jest przede wszystkim rasowa, następnie stanowiska społecznego, wreszcie przeciętnego poziomu wykształcenia, natomiast prawie cała treść kultury jest ta sama, gdyż Murzyni amerykańscy żyją kulturą białych, nie mają odrębnej kultury własnej, prócz pewnych przeżytków magicznych oraz nielicznych oryginalnych przyczynków w dziedzinie sztuki i poezji ludowej, języka i układów społecznych. Czy można na podstawie tych różnic określić Murzynów w ogóle jako po prostu i bez zastrzeżeń obcych w odniesieniu do białych? Oczywiście nie, gdyż w takim razie, jak określilibyśmy w porównaniu z nimi ludzi, którzy do powyższych różnic dołączają różnice treści kulturalnej tak głębokiej, jak np. imigranci chińscy, dalej ludzi o innej kulturze, stanowisku i wykształceniu, lecz stosunkowo mało różniących się rasowo, jak imigranci polscy lub włoscy, wreszcie ludzi podobnych kulturą i stanowiskiem, i poziomem wykształcenia, i rasą, a różniących się tylko przynależnością państwową i świadomością narodową, jak Anglicy (Znaniecki, 1931, s. 14).

Na tej podstawie Znaniecki stwierdza, że o obcości nie stanowią różnice obiektywne, lecz decydują o niej subiektywne oceny. Ponadto dodaje, że ci sami ludzie dla tych samych ludzi mogą raz okazać się "swoimi”, a innym razem "obcymi”.

Taką zmienność w postrzeganiu tych samych ludzi można zaobserwować, na przykład, na Kresach południowo-wschodnich. Polacy, mieszkający w tej samej co Ukraińcy wsi, byli przed wybuchem II wojny światowej najczęściej postrzegani jako „swoi". Kiedy nastąpiła gwałtowna zmiana społeczna, jaką była wojna i rozprzestrzeniająca się ideologia ukraińskiego nacjonalizmu, ci sami Polacy stawali się dla tych samych Ukraińców „obcymi". Słusznie Znaniecki postawił tezę, która jest zarazem socjologiczną definicją obcego. Brzmi ona: „Przedmiot ludzki doświadczany jest przez podmiot ludzki jako obcy zawsze wtedy i tylko wtedy, gdy zachodzi między nimi styczność społeczna na podłożu rozdzielnych układów wartości" (Znaniecki, 1931, s. 22). Zgodnie z tym każdorazowe wyjaśnienie obcości musi być poparte opisem warunków, okoliczności, sytuacji i zmieniającego się charakteru styczności. Definicja „obcego” Znanieckiego pozwala ponadto dostrzec bliskość znaczeniową tego pojęcia z pojęciem "wroga”. Socjolog ten bowiem mówi o "rozdzielnych układach wartości". Gdy zatem w miejsce słowa "obcy" wstawi się słowo „Wróg”, definicja nabiera większej klarowności.

Znaniecki wyróżnił cztery rodzaje wrogości. W pierwszym z nich działanie społeczne zmierza do zapobiegnięcia kontaktom społecznym między społecznym podmiotem (agent) a społecznym przedmiotem poprzez unikanie wspólnych doświadczeń. Takie działanie zostało określone mianem unikania. Można je zaobserwować w przypadku stosunków rasowych i klasowych. Drugi typ wrogości Znaniecki nazywa odrazą. Polega on na społecznym działaniu zmierzającym do wyeliminowania postaw przedmiotu społecznego ze sfery wartościowania podmiotu. Trzeci rodzaj wrogości zachodzi wówczas, gdy działania zmierzają do udaremnienia działalności społecznego przedmiotu przez przeciwdziałanie jej. Zdaniem polskiego naukowca w takim przypadku najwłaściwszy jest termin wrogiej walki (Znaniecki, 1931, s. 62). W przypadku zaś działań świadomie niszczących system wartości spotecznego przedmiotu, ale nie przez to, co może on zrobić podmiotowi, lecz co już uczynił (analiza przeszłości). Jest to czwarty rodzaj wrogości (Znaniecki, 1931, s. 62).

Dla F. Znanieckiego interesującym tematem były również konflikty między grupami kulturowymi, a przede wszystkim etnicznymi. We Współczesnych narodach wyjaśnia on problem antagonizmów, w wyniku których może zrodzić się konflikt. Pisze na ten temat następująco:

Gdy weźmiemy pod uwagę to, że antagonizm może mieć charakter indywidualny lub grupowy, wskazać można cztery jego odmiany, odróżniające się od siebie jedynie analitycznie. Po pierwsze, mamy antagonizm, którego i podmiot, i przedmiot jest zbiorowy. Przykładem jest stosunek między plemieniem, sektą lub narodem a obcym plemieniem, sektą lub narodem. 
Po drugie, spotykamy antagonizm, którego podmiot jest indywidualny, a przedmiot zbiorowy. Przykładem jest nienawiść jednostki do obcej grupy, od której we własnym mniemaniu doznata ona krzywdy. Po trzecie, mamy antagonizm, którego podmiotem jest zbiorowość, a przedmiotem jednostka (...). Ostatni antagonizm to relacja między indywidualnym podmiotem a indywidualnym przedmiotem (Znaniecki, 1990, ss. 330-331).

Janusz Mucha zauważa, że tak przedstawione antagonizmy nie są stosunkami społecznymi, gdyż nie zachodzą relacje dwustronne, ale stanowią podstawę takich stosunków (Mucha, 2006, ss. 64-65).

F. Znaniecki w wyżej wymienionej publikacji rozpatruje także kwestię konfliktów między narodami. Proponuje, aby badanie takich konfliktów rozpoczynać od analizy stosunków między skonfliktowanymi narodami w okresie poprzedzającym wybuch wzajemnej wrogości, sugerując, iż te stosunki były kiedyś pokojowe. Za naturalne uznaje dążenie narodów do ekspansji, która nie musi powodować konfliktów. Dopiero gdy dany naród kosztem innego celowo dąży do ekspansji lub jeśli ekspansja jednego narodu stanowi przeszkodę dla ekspansji drugiego dochodzi do agresji.

Oprócz L. Gumplowicza i F. Znanieckiego także inni teoretycy zajmowali się konfliktami społeczno-etnicznymi.

\section{KONCEPCJE KONFLIKTÓW ETNICZNYCH W UJĘCIU KLASYKÓW SOCJOLOGII}

Geneza teorii konfliktowych wywodzi się w gtównej mierze z opracowań teoretycznych K. Marksa, G. Simmela i M. Webera. Stworzone przez nich idee wciąż dostarczają inspiracji współczesnym orientacjom konfliktowym (L. A. Coser, R. Dahrendorf, H. Blumer).

Teoria konfliktu K. Marksa odnosi się przede wszystkim do konfliktu między klasami społecznymi i należy ją interpretować szczególnie z perspektywy ekonomicznej. Przywołanie jej w tym miejscu ma na uwadze jedynie przypomnienie, iż teorie konfliktu mają swe źródło w pracach Marksa. Uważał on, iż nierówny rozdział dóbr w systemie wywołuje wewnętrzny konflikt interesów, a kiedy podporządkowane zbiorowości stają się świadome swoich interesów, zaczynają kwestionować legitymację systemu. Tę teorię zdawali się wykorzystać, na przykład, propagandziści skrajnego ukraińskiego nacjonalizmu, którzy z braku mocnych argumentów natury politycznej zaczęli wykorzystywać argumenty ekonomiczne i socjalne, wskazując na gorszą w stosunku do Polaków pozycję społeczną i ekonomiczną Ukraińców jako mniejszości w państwie polskim. Sprzyjało temu to, że w przeszłości obszary dworskie były w większości polskie, dlatego z łatwością przychodziło im skierowanie nienawiści na „polskiego pana”, a za nim na każdego Polaka, choćby nawet bezrolnego chłopa. Według Lucyny Kulińskiej,

z analizy dokumentów OUN wynika że, zdaniem skrajnych nacjonalistów, jedynym powodem ciężkiego położenia ekonomicznego ukraińskiego chłopstwa była polityka powojennych rządów polskich. Pomijano fakt, że II Rzeczpospolita trwała lat niespełna 20, a zmagać się musiała ze spuścizną zaborów, wojennymi zniszczeniami i wielkim światowym kryzysem ekonomicznym. Wszystkie te problemy dotykały nie tylko Ukraińców, ale i Polaków (Kulińska, 2009, s. 61).

O tym jednak propaganda antypolska nie wspominała. Ważne było znalezienie wroga, który stoi na drodze do dobrobytu narodu ukraińskiego.

G. Simmel, podobnie jak K. Marks, postrzegat konflikt jako wszechobecny. Skupił się na badaniu konfliktu, którego skutki są pozytywne, sprzyja on bowiem solidarności i uni- 
fikacji. Według Simmla konflikt może zapewnić spoistość grupy ze względu na zdolność mobilizacji odczuć i siłę centralizującą wspólnotę. Nie znaczy to, że Simmel nie uznawał możliwości występowania konfliktów gwałtownych. Wręcz przeciwnie, uważat, że konflikt gwałtowny jest rezultatem pobudzenia emocjonalnego, które jest szczególnie możliwe wówczas, gdy grupy konfliktowe wyłaniają się z kontekstu stosunków pierwotnie harmonijnych. Obserwacja stosunków etnicznych i społecznych panujących na Kresach wschodnio-południowych II Rzeczypospolitej wydaje się potwierdzać spostrzeżenie Simmla. Rusini, nazywający się później Ukraińcami, i Polacy, zwłaszcza na wsi, od lat żyli ze sobą w zgodzie, czego potwierdzeniem mogą być choćby zawierane małżeństwa mieszane. Wskutek podsycanego przez okupantów konfliktu i frustracji związanej z potraktowaniem Ukraińców przez Niemców doszło do eskalacji konfliktu, a jego gwałtowność doprowadziła do ludobójstwa.

Krytycznie wobec Marksowskiej teorii konfliktu ustosunkował się M. Weber, według którego konflikt nie musi być nieuchronny, ale „jest bardziej prawdopodobny, kiedy resentymenty strony podporządkowanej zostaną zmobilizowane przez charyzmatycznych przywódców" (Turner, 2004, s. 181). Jednak ci przywódcy, gdy odniosą sukces, tworzą reguły, procedury i struktury, powodując powstanie nowego systemu panowania tradycyjnego, a to grozi odnowieniem konfliktu. Potencjał konfliktowy można jednakże ograniczyć, przestrzegając równego stosowania praw i regut.

L. A. Coser za Simmlem uznawał konflikt za stan w pewnych okolicznościach podtrzymujący żywotność systemów społecznych. Warunkiem jest jednak stabilność fundamentów struktury społecznej. Wtedy konflikt może być wyzwaniem, uświadomieniem wartości i celów, na które do tej pory członkowie grupy nie zwracali szczególnej uwagi, gdyż uznawane były za naturalne (Mucha, 1978, s. 108). Amerykański socjolog wykazywał, że konflikty w życiu społecznym przyczyniają się również do wzrostu integracji społecznej w obrębie grup ze sobą skonfliktowanych. Kluczowe w jego teorii jest rozróżnienie konfliktu rzeczywistego i nierzeczywistego (Coser, 2009, s. 38). Konflikt rzeczywisty „polega na dążeniu do osiągnięcia określonych celów, skierowanym przeciw rzeczywistym źródtom wrogości, przy akceptacji kosztów, jakie zostaną poniesione w toku działania" (Turner, 2004, s. 198). Natomiast konflikt nierzeczywisty toczy się wokół takich problemów, jak wartości ostateczne, przekonania, ideologie i niejasno zdefiniowane interesy klasowe, czyniąc go gwałtownym. Coser zauważa, że „nie są one spowodowane konkurencyjnymi z sobą celami antagonistów, lecz potrzebują uwolnienia napięcia przez co najmniej jednego z nich" (Coser, 2009, s. 39). W tym kontekście autor Funkcji konfliktu społecznego przywołuje przykład antysemityzmu jako konfliktu nierzeczywistego, w którym Żydzi służą jedynie jako obiekt do wyładowania agresji, będącej wynikiem frustracji. Zamiast Żydów mogą jako taki obiekt służyć także inne grupy, dla agresora nie ma to znaczenia (Coser, 2009, s. 39).

Poddając analizie problem związku istnienia wrogości w grupie z bliskimi stosunkami społecznymi w jej obrębie, który już wcześniej został podjęty przez Simmla, Coser uzależnia moc tych stosunków od zaangażowania emocjonalnego członków grupy. Stwierdza, że im bardziej angażują się oni w życie grupowe, tym większą wykazują tendencję do ukrywania wrogich uczuć, ale również większą wrażliwość na to, jak zachowują się członkowie grupy (Mucha, 1978, s. 116). Wpływ na ujawnienie wrogości mają także systemy. Te, które utrudniają ujawnienie wrogości, Coser nazywa systemami sztywnymi. W takich przypadkach wrogość niemająca normalnego ujścia często znajduje je w instytucji „kozła ofiarnego". Wymierzana jest ona nie przeciwko rzeczywistemu wrogowi, lecz jednostce lub grupie słabszej, którą łatwo pokonać i oskarżyć o nieprzyjazne dążenia. Agresja prze- 
mieszcza się więc z wroga rzeczywistego na inny obiekt. Z kolei twórca koncepcji konfliktu systemy, w których istnieje możliwość natychmiastowego ujawnienia wrogości określa mianem systemów luźnych (Coser, 2009, ss. 82-84).

W podobnym duchu na temat konfliktów społecznych wypowiada się niemiecki socjolog R. Dahrendorf, który domaga się miejsca w socjologii dla "konfliktowego modelu społeczeństwa". Według jego założeń,

1. Każde społeczeństwo w każdym momencie podlega procesom zmiany - zmiana jest wszechobecna.

2. W każdym społeczeństwie w każdym momencie występuje niezgoda i konflikt - konflikt społeczny jest wszechobecny.

3. Każdy element w społeczeństwie przyczynia się do jego dezintegracji i zmiany.

4. Każde społeczeństwo opiera się na przymusie stosowanym przez jednych jego członków w stosunku do innych (Dahrendorf, 1975, s. 433).

Różnice narodowe i etniczne stanowią podłoże wielu współczesnych konfliktów. Tego rodzaju sporom towarzyszy bardzo wysoki poziom emocji, w związku z czym pełnią one szczególną rolę. Niekiedy włącza się w nie cała społeczność żyjąca na danym obszarze. Jeszcze większą moc mają ideologie nacjonalistyczne, które są w stanie zaabsorbować wszystkie warstwy społeczne, czego przykładem mogą być Niemcy w okresie międzywojennym. Często z konfliktami na tle narodowościowym idzie w parze zmuszanie całych grup narodowościowych do opuszczenia zamieszkanych przez nie obszarów, zwane czystkami etnicznymi. Uczestnicy konfliktu posługują się przy tym narzędziami terroru i zastraszania. Czystki etniczne mogą przybrać formę masowych morderstw. Pierwszą wielką eksterminacją było ludobójstwo Ormian z rąk Turków w latach 1915-1917 (Płatek, 2011, ss. 73-84). Szacuje się, że w jej wyniku śmierć poniosło ponad milion mieszkańców ormiańskiego pochodzenia w rozpadającym się imperium osmańskim. W samookreśleniu się etnicznych i narodowych zbiorowości kluczową rolę odgrywa religia, która bywa wykorzystywana jako narzędzie pozwalające określonym grupom społecznym odróżnić się od innych, dlatego często dochodzi do nakładania się konfliktów religijnych na etniczne. Konflikty takie są przeważnie niezwykle zaciekłe.

Ciekawymi spostrzeżeniami na temat zachowań zbiorowych dzieli się w swoich pracach H. Blumer. Przykładami są dla niego zachowania tłumu, przejawy paniki, manie, popłoch, zachowania masowe, opinia publiczna, propaganda, ruchy społeczne, rewolucje czy reformy (Mucha, 2006, s. 120). Na znaczną część zachowań zbiorowych mają wpływ wspólne oczekiwania i podobne rozumienia świata, ale na niektóre taka wspólnota nie oddziałuje. Jednym z rodzajów interakcji społecznej jest reakcja kolista ${ }^{1}$, stymulująca zachowania w zbiorowościach i upodabniająca ludzi do siebie. Natomiast interakcja interpretacyjna odróżnia ludzi od siebie. „Tutaj istoty ludzkie reagują na siebie nawzajem przez wzajemne interpretowanie swoich działań i uwag oraz działają na podstawie tych właśnie interpretacji" (Mucha, 2006, s. 122).

Wyroste na gruncie amerykańskim teorie związane z uprzedzeniami etnicznymi i rasowymi odnoszą się przede wszystkim do sytuacji społecznej panującej w Stanach Zjednoczonych, jednakże na niektóre aspekty warto zwrócić uwage także w odniesieniu do europejskiej rzeczywistości. Blumer nawiązuje do sytuacji społecznych generujących uprzedzenia rasowe i zauważa, że spośród dwóch grup współżyjących na pewnym terenie jedna z nich dominuje, a druga jest podporządkowana, a więc żyją one w stanie przy-

1 Analiza zachowań zbiorowych opiera się na przyjętej od Parka koncepcji kolistej reakcji. Należy ją rozumieć jako szczególną formę interakcji. Zob. Hałas (1994, s. 58). 
stosowania lub symbiozy. Grupa dominująca spodziewa się akceptacji swej pozycji przez grupę podporządkowaną, ale jednocześnie obawia się, że grupa podporządkowana będzie się domagać dostępu do szans i przywilejów, których została pozbawiona. „Im większy jest odczuwany przez grupę dominującą strach, tym większe jest prawdopodobieństwo pojawienia się uprzedzeń wobec zbiorowości subiektywnie jej zagrażających" (Mucha, 2006, s. 137). Uprzedzenia zaś nie pojawiają się automatycznie, lecz kształtują się stopniowo. Początkowe incydenty traktować się powinno jako oznaki mogących w przyszłości nastąpić bardziej trwałych i zagrażających grupie ataków.

H. Blumer proponuje analizę stosunków rasowych (narodowych) z perspektywy realnych działań ludzi, ich kontaktów bezpośrednich i pośrednich. Jego zdaniem,

Trzeba przebadać strukturę interesów i strukturę kontroli w danych sytuacjach. Trzeba zidentyfikować powody, dla których stosunek społeczny nie rozpada się. W tym celu należy wziąć pod uwage utrwalone interesy, ustabilizowane stosunki władzy, inercje instytucji, funkcjonowanie kodów społecznych, środki zastraszania, ustabilizowaną strukturę szans życiowych, reakcje urzędników i polityków (Mucha, 2006, s. 152).

W złożonym społeczeństwie masowym ważną rolę odgrywają kontakty pośrednie, polegające głównie na stosunkach między organizacjami a ich reprezentantami.

Powyższe rozważania inspirują także do psychologicznej interpretacji wrogości między grupami etnicznymi.

\section{PRÓBA PSYCHOLOGICZNEGO WYJAŚNIENIA WROGOŚCI WOBEC "OBCYCH" ( „INNYCH")}

P. Zimbardo, jeden z najbardziej cenionych współcześnie psychologów społecznych, podjął rozważania na temat systemów tworzących hierarchie dominacji. Zadaje on pytanie, czego potrzebują obywatele jednej społeczności, aby znienawidzić do tego stopnia członków innej społeczności, by chcieć ich odseparować, a nawet zabić. Odpowiedź znajduje w psychologicznej konstrukcji - „nienawistnej wyobraźni”. Zauważa on, że:

Proces rozpoczyna się od stworzenia stereotypowego obrazu innego człowieka, jego zdehumanizowanego postrzegania jako bezwartościowego, ale zarazem wszechpotężnego Obcego, istoty demonicznej, abstrakcyjnego potwora, jako fundamentalnego zagrożenia dla czczonych przez nas wartości i przekonań (...). Z najbardziej ekstremalnym wydaniem oddziaływania tej wrogiej wyobraźni mamy oczywiście do czynienia wtedy, gdy prowadzi ona do ludobójstwa, równoznacznego z dążeniem jednych ludzi do eliminacji wszystkich tych, którzy zostali zdefiniowani jako ich wrogowie (Zimbardo, 2012, ss. 33-34).

Autor odwołuje się do propagandy Hitlera, która doprowadziła do tego, że żydowscy sąsiedzi, współpracownicy, a nawet przyjaciele stali się nagle znienawidzonymi wrogami państwa. Podobieństwo można odnaleźć również w kresowej rzeczywistości. Ukraińska nacjonalistyczna propaganda także spowodowała, że polscy sąsiedzi, przyjaciele, a nawet członkowie rodziny stali się znienawidzonymi wrogami, których należy wyeliminować. Wzniecenie nienawiści jako narzędzia w walce o niepodległość stawiali sobie za cel czołowi ideolodzy skrajnego ukraińskiego nacjonalizmu. Prowadzona przez nich agitacja miała nakłaniać Ukraińców do nieposłuszeństwa polskim władzom i ustawom oraz krzewić nienawiść do wszystkiego, co polskie. „Biuletyn Krajowej Egzekutywy OUN” z 1931 roku informuje: 
Naszym narodowym wrogiem, który nas niszczy i nie dopuszcza do stworzenia samodzielnego państwa, są nie tylko urzędy stojące na czele państw, które okupują nasze ziemie i ujarzmiają nas, Ukraińców. Naszymi wrogami są i ci, z woli których te urzędy panują, konkretnie mówiąc w Polsce - Polacy (Kulińska, 2009, s. 52).

Systematycznie wpajana idea nienawiści do obcych w postaci skrajnego ukraińskiego nacjonalizmu znalazła gorliwych wyznawców w Małopolsce Wschodniej i na Wołyniu, doprowadzając do ludobójstwa Polaków tam mieszkających.

Zimbardo wprowadza pojęcie czynnika dehumanizacji jako jednego z aspektów tego skomplikowanego procesu psychologicznego. Dla zobrazowania problemu posługuje się przykładem ludobójstwa w Rwandzie, gdzie rządzące plemię Hutu dokonało eksterminacji mniejszości Tutsi. Hutu, w większości zwykli farmerzy, w okrutny sposób mordowali na rozkaz swoich sąsiadów i przyjaciół. Prowadzi to do wniosku, że "istoty ludzkie są zdolne do całkowitego porzucenia swego człowieczeństwa dla bezdusznej ideologii, wykonując - lub wręcz wyprzedzając - rozkazy charyzmatycznej władzy, nakazujące niszczenie każdego, kto został określony jako «Wróg»" (Zimbardo, 2012, s. 37).

Tak przedstawioną koncepcję uzupełnić może dobrze znana psychologia tłumu. G. Le Bon wprowadza pojęcie duszy zbiorowej, która jego zdaniem każe jednostkom stanowiącym tłum myśleć, działać i czuć w inny sposób, aniżeli by myślała, działała i czuła każda jednostka z osobna. Ta specyficzność tłumu ma kilka przyczyn. Jedną z nich jest poczucie anonimowości w tłumie i w związku z tym brak odpowiedzialności, drugą - zaraźliwość uczuć i czynów, dzięki której jednostka może poświęcić osobiste cele na rzecz wspólnych. Za trzecią i najistotniejszą przyczynę ten wnikliwy obserwator ludzi działających w grupie uznał nabywanie przez jednostkę znajdującą się $w$ tłumie przeciwnych cech do tych, jakie każda z osób posiada indywidualnie. Chodzi tutaj o podatność na sugestie, która wynika ze wspomnianej już zaraźliwości. Zdaniem francuskiego psychologa i socjologa jednostka w tłumie traci świadomość swych czynów i pod wpływem sugestii zdolna jest wykonywać pewne czyny z nadzwyczajną gwałtownością. Le Bon pisze:

\footnotetext{
Jednostkę w tłumie cechuje: zanik świadomości swego «ja», przewaga czynników nieświadomych, kierowanie myślami i uczuciami przez sugestię i zaraźliwość, a ponadto dążenie do jak najszybszego urzeczywistnienia sugerowanych idei. Jednostka przestaje być samą sobą, staje się automatem, którym kieruje wola narzucona, nigdy zaś własna.

Każda jednostka, stając się cząstką tłumu, zstępuje tym samym o kilka stopni niżej w swym rozwoju kulturowym. Jako jednostka posiada pewną kulturę, w tłumie zaś staje się istotą dziką i niewolnikiem instynktów. Ma spontaniczność, gwałtowność i okrucieństwo, ale równocześnie bohaterstwo i entuzjazm pierwotnego człowieka (...). Jednostka w tłumie to ziarnko piasku wśród innych ziarenek, którym wiatr miota według własnego kaprysu (Le Bon, 2009, s. 19).
}

Ważną rolę w tłumie odgrywa jego przywódca, który zanim stanie się panem mas i krzewicielem danej idei, sam musi wpierw ulec jej urokowi. Jego zadaniem jest wzbudzenie w tłumie wiary, jaką sam już posiada i zamienienie jednostki w niewolnika własnych przekonań. Aby tego dokonać, wódz odwołuje się do trzech metod: twierdzenia, powtarzania, zaraźliwości. Twierdzenie, pozbawione wszelkiego rozumowania, niepoparte żadnymi dowodami, a nawet inne niż znana tłumowi rzeczywistość staje się najlepszą metodą zaszczepienia masom jakiejś idei. Wystarczy je w tej samej formie ustawicznie powtarzać, aby zarazić ideą całą zbiorowość, przy czym jednostki stanowiące tłum niekoniecznie muszą przebywać w tym samym miejscu (Le Bon, 2009, ss. 58-61).

Zbiorowość, która po pewnym czasie staje się bezświadomym automatem wrażliwym na sugestie przywódców Le Bon za innymi psychologami nazywa tłumem zbrodniczym. 
Podobnie jak inne rodzaje tłumów również zbrodniczy posiada te same cechy, czyli łatwowierność, podatność na sugestie, zmienność, przesadę uczuć i specyficzną moralność. Le Bon przywołuje tu przykład zachowania tłumu w czasie rewolucji francuskiej, który we wrześniu 1792 roku wymordował więźniów, najczęściej arystokratów i księży, opowiadających się rzekomo za przywróceniem monarchii absolutnej. Jednostki stanowiące zbiorowość, ulegające tej sugestii, przekonane były, iż czynią dobrze, wręcz wykonują swój obowiązek patriotyczny. W tym przekonaniu, aby nie sądzić osobno każdego więźnia, postanowiono wymordować wszystkich należących do wyższej klasy społecznej. Chociaż rzeź prowadzona była ze szczególnym okrucieństwem, wśród śpiewów i tańców panowała powszechna wesołość. A w poczuciu specyficznej sprawiedliwości nie pozwalano, by przyjemność zabicia arystokraty kogokolwiek ominęła, więc przywilej zadania ciosu ofierze dzielili wszyscy uczestniczący w zbrodni (Le Bon, 2009, ss. 77-78). Podobne obrazy powszechnej wesołości panującej przy dokonywaniu zabójstwa ze szczególnym okrucieństwem zauważyć można w opisującej ludobójstwo Polaków przez ukraińskich nacjonalistów literaturze kresowej.

Z działaniami tłumu niejednokrotnie łączy się pojęcie agresji, którego najprostsza definicja brzmi: „zamierzone zachowanie mające na celu spowodowanie cierpienia fizycznego lub psychicznego" (Aronson, 2011, s. 250). Dużą rolę w badaniach nad agresją odegrała teoria J. Dollarda i N. E. Millera, w myśl której agresja jest popędem nabytym, będącym reakcją na frustrację, zawsze pojawiającą się w sytuacji, gdy reakcja ukierunkowana na cel zostaje zablokowana. Im większa frustracja, tym silniejsza wynikająca z niej agresywna reakcja (Zimbardo \& Gerrig, 1997, s. 586).

Także amerykański psycholog E. Aronson za główny czynnik wywołujący agresję uznaje frustrację. Przywołując różne eksperymenty badające ten problem, dochodzi on do wniosku, że frustracja osiąga swe apogeum wtedy, gdy dany cel jest już bliski a oczekiwania duże i gdy nagle dążenie do celu zostało zablokowane bez właściwego uzasadnienia.

To w pewien sposób tłumaczy zachowanie ukraińskich nacjonalistów ukazane w powieściach. Spełnienie marzeń o „samostijnej Ukrainie” wydawało się bliskie. Ukraińcy liczyli, że za pomoc okazaną niemieckim nazistom przy okupacji Kresów, hitlerowcy pomogą im zbudować państwo ukraińskie. Z niezrozumiałych dla nich powodów Niemcy nie zamierzali jednak ofiarować im oczekiwanej wolnej Ukrainy, w wyniku czego narastała frustracja, która znalazła swe ujście w agresji skierowanej przeciwko Polakom i innym grupom etnicznym. Takie zachowanie z kolei wiąże się z koncepcją "kozłów ofiarnych", czyli agresją przemieszczoną. Jeśli nie jest możliwe wzięcie odwetu na bezpośredniej przyczynie frustracji, bo okazuje się nią siła zbyt potężna lub zbyt nieokreślona, jednostka, a także dana zbiorowość, bierze odwet na „koźle ofiarnym”, czyli kimś niewinnym i często bezsilnym, komu przypisano odpowiedzialność za coś, co nie było jego winą.

Tą teorią tłumaczono na przykład agresję hitlerowskich Niemiec wobec Żydów. W Niemczech po I wojnie światowej inflacja rosła z dnia na dzień, ludzie zaś byli krańcowo biedni, zdemoralizowani i sfrustrowani. Kiedy w latach trzydziestych naziści doszli do władzy, uczynili wszystko, by skoncentrować frustrację Niemców na Żydach, którzy byli łatwą do zidentyfikowania grupą obcą, pozbawioną władzy. Stworzono więc wrażenie, że gdy pozbawi się praw publicznych Żydów, a w końcu wyeliminuje ich ze społeczeństwa, znikną wszystkie niemieckie problemy. Żydzi stali się więc łatwym do zidentyfikowania „kozłem ofiarnym". W ten sposób agresja została przemieszczona z trudnych do zidentyfikowania przyczyn złego stanu gospodarki na widoczną, acz nielubianą i słabą, obcą grupę. W podobny sposób można tłumaczyć uczynienie przez Ukraińców „kozłów ofiarnych” 
z Polaków na Kresach południowo-wschodnich II Rzeczypospolitej. Ukraińcy byli najliczniejszą tam grupą narodowościową, nierzadko stanowili ponad połowę mieszkańców, a na Wołyniu dominowali niemal zupełnie. Napad Niemiec hitlerowskich na Polskę i jej porażka w kampanii wrześniowej stały się dla nacjonalistów ukraińskich świetną okazją do ziszczenia nadziei na utworzenie państwa ukraińskiego. Przeszkodą w ich przekonaniu był bezbronny żywioł polski mieszkający na Kresach południowo-wschodnich. Wróg okazał się łatwy do zidentyfikowania i na dodatek słaby, więc dla szowinistów ukraińskich nadawał się do roli „kozła ofiarnego”, jak dla hitlerowców Żydzi. Gorliwość, z jaką starali się wytępić Polaków, wskazuje na wspótistnienie oprócz czynników politycznych, także czynników natury psychologicznej. Prowadzi to do wniosku, że „ludzie są skłonni do przemieszczania agresji na grupy, które rzucają się w oczy, są względnie bezsilne i od początku nielubiane" (Aronson, 2011, s. 323).

\section{ZAKOŃCZENIE}

Konflikty etniczne należą do skomplikowanych zagadnień społecznych. Ich zrozumienie i interpretacja zależą od czynników kulturowych i psychologicznych. Z uwagi na to trzeba tu odwołać się do znanych teorii konfliktów etnicznych prezentowanych przez socjologów L. Gumplowicza i F. Znanieckiego oraz do teoretyków klasycznej teorii konfliktów społecznych, jak i do współczesnych badaczy konfliktów etnicznych.

Konflikty te mają również aspekt psychologiczny, który winien być uwzględniony w badaniach konfliktów społeczno-etnicznych. Włączenie tego punktu widzenia do badań pozwala na wnikliwsze spojrzenie na problem.

Konflikty etniczne zarówno w aspekcie socjologicznym, jak i psychologii społecznej, nacechowane dużym stopniem agresji, mogą narastać i prowadzić nawet do ludobójstwa. Znajomość tych prawideł pozwala zrozumieć przyczyny okrucieństwa, które jest nieodłącznie związane z masowymi mordami na tle narodowościowym. Konflikty na tle narodowościowym były bowiem jedną z wielu przyczyn martyrologii na Kresach południowowschodnich II Rzeczypospolitej. Skomplikowana ówczesna sytuacja geopolityczna Europy sprzyjała ich eskalacji na tym terenie.

\section{BIBLIOGRAFIA}

Aronson, E. (2011). Człowiek - istota społeczna. (J. Radzicki, Tłum.). Warszawa: Wydawnictwo Naukowe PWN.

Coser, L. A. (2009). Funkcje konfliktu społecznego. (S. Burdziej, Tłum.). Kraków: Zakład Wydawniczy NOMOS.

Dahrendorf, R. (1975). Teoria konfliktu w społeczeństwie przemysłowym. W W. Dereczyński, A. Jasińska-Kania, \& J. Szacki (Red.), Elementy teorii socjologicznych: Materiaty do dziejów współczesnej socjologii zachodniej (ss. 429-463). Warszawa: PWN.

Hałas, E. (1994). Obywatelska socjologia szkoły chicagowskiej: Charles H. Cooley, George H. Mead, Herbert Blumer. Lublin: Redakcja Wydawnictw KUL. 
Kulińska, L. (2009). Działalność terrorystyczna i sabotażowa nacjonalistycznych organizacji ukraińskich w Polsce w latach 1922-1939. Kraków: Księgarnia Akademicka.

Le Bon, G. (2009). Psychologia tłumu. (B. Kaprocki, Tłum.). Kęty: Wydawnictwo Marek Derewiecki.

Mirek, F. (1930). System socjologiczny Ludwika Gumplowicza. Poznań: Księgarnia I. Zamecznika.

Mucha, J. (1978). Konflikt i społeczeństwo: Z problematyki konfliktu społecznego we wspótczesnych teoriach zachodnich. Warszawa: Państwowe Wydawnictwo Naukowe.

Mucha, J. (2006). Stosunki etniczne we wspótczesnej myśli socjologicznej. Warszawa: Wydawnictwo Naukowe PWN.

Płatek, D. (2011). Pomiędzy Imperium Osmańskim a Republiką Turecką: Proces narodowotwórczy i ludobójstwo w ujęciu socjologii historycznej (ss. 73-84). Pobrano 15 września 2014, z http://www.academia.edu/4114968/LUDOB\%C3\%93JSTWO_ ORMIAN_W_UJ\%C4\%98CIU_SOCJOLOGII_HISTORYCZNEJ

Szacki, J. (2011). Historia myśli socjologicznej. Warszawa: Wydawnictwo Naukowe PWN.

Turner, J. H. (2004). Struktura teorii socjologicznej. (G. Woroniecka i in., Tłum). Warszawa: Wydawnictwo Naukowe PWN.

Zimbardo, P. G. (2012). Efekt Lucyfera. (A. Cybulko i in., Tłum.). Warszawa: Wydawnictwo Naukowe PWN.

Zimbardo, P. G., \& Gerrig, R. J. (1997). Psychologia i życie. (E. Czerniawska i in., Tłum.). Warszawa: Wydawnictwo Naukowe PWN

Znaniecki, F. (1931). Studia nad antagonizmem do obcych. Poznań: Rolnicza Drukarnia i Ksiegarnia Nakładowa.

Znaniecki, F. (1971). Nauki o kulturze: Narodziny i rozwój. Warszawa: Państwowe Wydawnictwo Naukowe.

Znaniecki, F. (1990). Współczesne narody. Warszawa: Państwowe Wydawnictwo Naukowe. 